medRxiv preprint doi: https://doi.org/10.1101/2020.05.16.20104315; this version posted May 28, 2020. The copyright holder for this preprint

(which was not certified by peer review) is the author/funder, who has granted medRxiv a license to display the preprint in perpetuity.

It is made available under a CC-BY-NC-ND 4.0 International license .

\title{
Modes of transmission of COVID-19 outbreak- a mathematical study
}

\author{
Chandan Maji ${ }^{\mathrm{a}}$ \\ ${ }^{a}$ Department of Mathematics, Vivekananda College, Thakurpukur, Kolkata-700063, India
}

\begin{abstract}
The world has now paid a lot of attention to the outbreak of novel coronavirus (COVID-19). This virus mainly transmitted between humans through directly respiratory droplets and close contacts. However, there is currently some evidence where it has been claimed that it may be indirectly transmitted. In this work, we study the mode of transmission of COVID-19 epidemic system based on the susceptibleinfected-recovered (SIR) model. We have calculated the basic reproduction number $R_{0}$ by next-generation matrix method. We observed that if $R_{0}<1$, then disease-free equilibrium point is locally as well as globally asymptotically stable but when $R_{0}>1$, the endemic equilibrium point exists and is globally stable. Finally, some numerical simulation is presented to validate our results.
\end{abstract}

Keywords: COVID-19; direct and indirect transmission; basic reproduction number; global stability;

\section{Introduction}

Today an invisible emperor of the world has put human civilization in front of a big question mark which is popularly known as COVID-19 (World Health Organization (WHO)). Mankind, proud of being the most advanced intelligent creature in the world is now endangered by its tyranny. COVID-19 is an abbreviated form of Severe Acute Respiratory Syndrome Coronavirus 2 (SARS-CoV-2), which has not been previously identified in humans [1]. On Dec, 2019, this disease was first identified in Wuhan city Hubei province of china [2], after that rapidly it has spread out all over the world. SARS [3] and MERS [4], these two previously known corona virus disease outbreaks have already occurred in the last two decades. Till now it is reported that COVID-19 has been spread out in more than 200 countries and now it has taken the shape of an epidemic in worldwide with more than 3.8 million people infected and 2.5 lakhs death [5].

It is presumed that COVID-19 is directly transmitted through human to human via respiratory droplets among closed contact and infected people generally develop signs and symptoms, including mild respiratory discomfort and fever, on an average of 5-6

\footnotetext{
${ }^{*}$ Corresponding author.Ph.:+919681106183

Email address: chandanmaji.ju@gmail.com (Chandan Maji)
}

Preprint submitted to medRXiv

NOTE: This preprint reports new research that has not been certified by peer review and should not be used to guide clinical practice. 
days after infection [6]. In [7], Jiang et al. estimated that fatality rate of this virus is near about $4.5 \%$ but for the age group 70-79 it has gone up to $8 \%$. This disease is more critical for elder people who has other diseases like diabetes, asthma, cardiovascular disease [6]. However, these transmission modes do not explain all cases. A lot of evidences have shown that COVID-19 has highly similar biological properties with severe acute respiratory syndrome coronavirus (SARS-CoV). In their study [8], Cai et al. investigated a cluster of COVID-19 cases associated with a shopping mall in Wenzhou, China and showed that indirect transmission of the causative virus occurred from virus contamination of common objects, virus aerosolization in a confined space, or spread from asymptomatic infected persons. Zhang et al. [9], suggested that transmission may also occur through fomites in the immediate environment around the infected person. Guo et al. [10], tested surface and air samples from an intensive care unit (ICU) and a general COVID-19 ward at Huoshenshan Hospital in Wuhan, China and found that contamination was greater in ICU than general wards, they also have seen that virus was widely distributed on floors, computer mice, trash cans, and sickbed handrails. Therefore, it can be concluded that the transmission of the COVID-19 virus can occur by direct contact with infected people and indirect contact with surfaces in the immediate environment or with objects used on the infected person. Considering direct transmission mode, already a lot of works have been done mathematically and numerically to give an efficient prediction on COVID 19 outbreaks $[11,12,13,14,15]$. Researchers are trying their best to discovering vaccines and treatments for the virus but it may be far away from our imagination [16]. In this work, we have formulated a mathematical model of direct and indirect transmission to study the dynamics of COVID-19 outbreaks.

The paper is organized as follows: In Section 2. we have formulated a mathematical model for the epidemic COVID-19. Boundedness of the solutions of system (1) is performed in Section 3. Stability analysis of disease-free equilibrium point is discussed in Section 4. Local and global stability of endemic equilibrium point is presented in section 5. Sensitivity analysis and some numerical simulations are discussed in Section 6, to validate our results. A brief discussion is given in Section 7.

\section{Model Formulation}

The world has now paid a lot of attention on the outbreak of novel coronavirus (COVID-19) which has been declared a pandemic by WHO. Till date, no vaccine or medicine is available to cure the disease properly so people are getting in a panic and they are afraid of disease transmission. According to current evidence, COVID-19 virus is primarily transmitted between people through respiratory droplets and close contacts $[17,18,19,20,21,22]$. But there are also some evidences who conclude that transmission may also occur through fomites in the immediate environment around the infected person $[9,23,24]$. Inspired by above all these work, we have formulated a epidemic model for COVID-19 of direct and indirect transmission. The model is based on traditional susceptible-infected-recovered (SIR) models of disease transmission in humans. Our proposed model is described by a system of four ordinary differential 
medRxiv preprint doi: https://doi.org/10.1101/2020.05.16.20104315; this version posted May 28, 2020. The copyright holder for this preprint (which was not certified by peer review) is the author/funder, who has granted medRxiv a license to display the preprint in perpetuity.

It is made available under a CC-BY-NC-ND 4.0 International license .

equation which is as follows:

$$
\begin{aligned}
\frac{d S}{d t} & =r-S\left(\beta_{i} I+\beta_{e} E\right)-\mu S \\
\frac{d I}{d t} & =S\left(\beta_{i} I+\beta_{e} E\right)-(\mu+d+\gamma) I \\
\frac{d R}{d t} & =\gamma I-\mu R \\
\frac{d E}{d t} & =\alpha I-\tau E
\end{aligned}
$$

with initial conditions $S(0)>0, I(0)>0, E(0) \geq 0, R(0) \geq 0$.

Here, $S(t), I(t)$ denotes the density of susceptible population, infected population. $R(t)$ is the total number of recovered population and $E(t)$ is the mass of infectious material present in the environment. All other model parameters and their description are given in Table 1.

\begin{tabular}{|l|l|}
\hline \multicolumn{2}{|c|}{ Table 1. Parameters and their descriptions } \\
\hline$r$ & recruitment rate of susceptible which includes immigrants and newborns \\
$\beta_{i}$ & direct disease transmission rate \\
$\beta_{e}$ & indirect disease transmission rate \\
$\mu$ & natural death rate \\
$d$ & disease induced death rate \\
$\gamma$ & recovery rate from infected population \\
$\alpha$ & infectious material in the environment \\
$\tau$ & loss of infectious material from the environment \\
\hline
\end{tabular}

\section{Boundedness}

For biological validity of system (1), it is necessary to prove that all solutions of system (1) with positive initial values will remain positive for all time $t>0$. Thus in this section we want to prove the positivity and boundedness of solutions of our considered system.

Lemma 1. All solutions $(S(t), I(t), R(t), E(t))$ of system (1) with positive initial values in $\mathbb{R}_{+}^{4}$ will remain positive for all $t>0$.

Proof. From first equation of system (1), we get

$\frac{d S}{d t}>-\left(\beta_{i} I+\beta_{e} E+\mu\right) S(t)$.

Thus, $S(t)>S(0) \exp \left\{-\int_{0}^{t}\left(\beta_{i} I+\beta_{e} E+\mu\right) d s\right\}>0$. 
As, $S(0)>0$ then $S(t)>0$ for all $t>0$.

Similarly, it can be shown that $I(t)>0, R(t)>0, E(t)>0$ for all $t>0$. Hence the interior of $R_{+}^{3}$ is an invariant set of system (1).

Lemma 2. All solution of system (1), which initiate in $\mathbb{R}_{+}^{4}$ are bounded and lie in the region $\Omega=\left\{(S, I, R, E) \in \mathbb{R}_{+}^{4}: S+I+R+E \leq \frac{r}{v}\right\}$.

Proof. Define a function, $W(t)=S(t)+I(t)+R(t)+\frac{d}{\alpha} E(t)$.

The time derivative along the solution of system (1), we get

$$
\begin{array}{r}
\frac{d W}{d t}=r-\mu S-(\mu+d+\gamma) I+\gamma I-\mu R+d I-\frac{d \tau}{\alpha} E \\
\leq r-\left[\mu(S+I+R)+\frac{d \tau}{\alpha} E\right] \leq r-v W, \text { where } v=\min \{\mu, \tau\} .
\end{array}
$$

By using differential inequality argument [25], we get

$$
W(t) \leq \frac{r}{v}+c e^{-v t}
$$

where $c$ is arbitrary positive constant. Hence we get, $W(t) \leq \frac{r}{v}$ when $t \rightarrow \infty$.

All solution of system (1) enter into the region $\Omega=\left\{(S, I, R, E) \in \mathbb{R}_{+}^{4}: S+I+R+\right.$ $\left.E \leq \frac{r}{v}\right\}$

\section{Stability analysis}

Basic reproduction number is one of the most important threshold parameter which can determine whether the infectious disease will die out or spread through population with time increases. Here we calculate the basic reproduction number for COVID-19 model through next generation matrix method [26].

System (1) has a unique disease free equilibrium point $E_{1}(K, 0,0,0)$, where $K=\frac{r}{\mu}$. Then using the notation in [26], the reproduction number $R_{0}$ of system (1) is given by

$$
R_{0}=\frac{K\left(\alpha \beta_{e}+\tau \beta_{i}\right)}{\tau(\mu+d+\gamma)}
$$

Theorem 1. Disease free equilibrium $E_{1}$ is locally as well as globally asymptotically stable if $R_{0}<1$ and unstable if $R_{0}>1$. 
medRxiv preprint doi: https://doi.org/10.1101/2020.05.16.20104315; this version posted May 28, 2020. The copyright holder for this preprint (which was not certified by peer review) is the author/funder, who has granted medRxiv a license to display the preprint in perpetuity.

It is made available under a CC-BY-NC-ND 4.0 International license .

Proof. The Jacobian matrix at $E_{1}$ is given by

$$
J\left(E_{1}\right)=\left(\begin{array}{cccc}
-\mu & -K \beta_{i} & 0 & -K \beta_{e} \\
0 & K \beta_{i}-(\mu+d+\gamma) & 0 & K \beta_{e} \\
0 & \gamma & -\mu & 0 \\
0 & \alpha & 0 & -\tau
\end{array}\right) .
$$

Therefore, all eigenvalues of the characteristic equation of $J\left(E_{1}\right)$ are $-\mu,-\mu$ and other two eigenvalues are the roots of the equation

$$
\lambda^{2}+p_{1} \lambda+p_{2}=0
$$

where, $p_{1}=\left(\mu+d+\gamma+\tau-K \beta_{i}\right), \quad p_{2}=\tau(\mu+d+\gamma)-K\left(\alpha \beta_{e}+\tau \beta_{i}\right)$.

Clearly, $p_{1}, p_{2}>0$ when $R_{0}<1$. Therefore all roots of equation (2) has negative real part, hence $E_{1}$ is locally asymptotically stable and unstable when $R_{0}>1$.

Now, we consider the following Lyapunov function to prove global stability of disease free equilibrium point $E_{1}$.

$$
V=\alpha I+(\mu+d+\gamma) E
$$

with Lyapunov derivative we obtain,

$$
\begin{aligned}
\frac{d V}{d t} & =\alpha S\left(\beta_{i} I+\beta_{e} E\right)-\alpha(\mu+d+\gamma) I+\alpha(\mu+d+\gamma) I-\tau(\mu+d+\gamma) E \\
& =\alpha S\left(\beta_{i} I+\beta_{e} E\right)-\tau(\mu+d+\gamma) E \\
& \leq \tau(\mu+d+\gamma)\left(R_{0}-1\right) E .
\end{aligned}
$$

Since, all parameters of the model are non negative. Hence, it follows that $\frac{d V}{d t}<0$ when $R_{0}<1$, hence by Lasalle invariance principle [27], the disease free equilibrium point is globally asymptotically stable.

\section{Endemic equilibrium and its stability analysis}

The endemic equilibrium point $E_{2}^{*}$ of the model (1) is given by

$$
S^{*}=\frac{(\mu+d+\gamma) \tau}{\tau \beta_{i}+\alpha \beta_{e}}, \quad I^{*}=\frac{\mu \tau\left(R_{0}-1\right)}{\tau \beta_{i}+\alpha \beta_{e}}, \quad R^{*}=\frac{\gamma \tau\left(R_{0}-1\right)}{\tau \beta_{i}+\alpha \beta_{e}}, \quad E^{*}=\frac{\mu \alpha\left(R_{0}-1\right)}{\tau \beta_{i}+\alpha \beta_{e}} .
$$

Clearly, we have seen that the endemic equilibrium point $E^{*}$ is feasible if $R_{0}>1$.

Theorem 2. Endemic equilibrium point $E_{2}^{*}$ is locally asymptotically stable if $R_{0}>1$. 
medRxiv preprint doi: https://doi.org/10.1101/2020.05.16.20104315; this version posted May 28, 2020. The copyright holder for this preprint

(which was not certified by peer review) is the author/funder, who has granted medRxiv a license to display the preprint in perpetuity.

It is made available under a CC-BY-NC-ND 4.0 International license .

Proof. The Jacobian matrix of system (1), at endemic equilibrium point $E_{2}^{*}$ is given by

$$
J\left(E_{2}^{*}\right)=\left(\begin{array}{cccc}
a_{11} & a_{12} & 0 & a_{14} \\
a_{21} & a_{22} & 0 & a_{24} \\
0 & a_{32} & a_{33} & 0 \\
0 & a_{42} & 0 & a_{44}
\end{array}\right)
$$

where $\quad a_{11}=-\mu R_{0}, \quad a_{12}=-\frac{\tau(\mu+d+\gamma)}{\tau \beta_{i}+\alpha \beta_{e}} \beta_{i}, \quad a_{13}=0, \quad a_{14}=-\frac{\tau(\mu+d+\gamma)}{\tau \beta_{i}+\alpha \beta_{e}} \beta_{e}$,

$$
\begin{gathered}
a_{21}=\mu\left(R_{0}-1\right), \quad a_{22}=-\frac{\alpha \beta_{e}(\mu+d+\gamma)}{\tau \beta_{i}+\alpha \beta_{e}}, \quad a_{23}=0, \quad a_{24}=\frac{\tau(\mu+d+\gamma)}{\tau \beta_{i}+\alpha \beta_{e}} \beta_{e} \\
a_{31}=a_{34}=a_{41}=a_{43}=0, \quad a_{32}=\gamma, \quad a_{33}=-\mu, \quad a_{42}=\alpha, \quad a_{44}=-\tau .
\end{gathered}
$$

Characteristic equation of $J\left(E_{2}^{*}\right)$ is given by

$$
\lambda^{4}+A_{1} \lambda^{3}+A_{2} \lambda^{2}+A_{3} \lambda+A_{4}=0,
$$

where, $A_{1}=-\left(a_{11}+a_{22}+a_{33}+a_{44}\right)$,

$$
\begin{aligned}
A_{2}= & a_{33}\left(a_{11}+a_{22}+a_{44}\right)+a_{11}\left(a_{22}+a_{44}\right)+a_{22} a_{44}-a_{24} a_{42}-a_{21} a_{12}, \\
A_{3}= & a_{11} a_{24} a_{42}+a_{12} a_{21} a_{44}+a_{12} a_{21} a_{33}+a_{24} a_{42} a_{33}-a_{11} a_{22} a_{44} \\
& -a_{22} a_{33} a_{44}-a_{11} a_{33}\left(a_{22}+a_{44}\right) \\
A_{4}= & a_{33}\left(a_{11} a_{22} a_{44}-a_{11} a_{24} a_{42}-a_{12} a_{21} a_{44}\right) .
\end{aligned}
$$

It follows from Routh-Hurwitz criteria [28] that all roots of equation (3) will have negative real parts if $A_{1}>0, A_{3}>0, A_{4}>0$ and $A_{1} A_{2}>A_{3}, \quad\left(A_{1} A_{2}-A_{3}\right) A_{3}>A_{1}^{2} A_{4}$. This will be possible when $R_{0}>1$. Hence, endemic equilibrium point $E_{2}^{*}$ is locally stable.

System (1) is said to be uniformly persistent if there exist a constant $\bar{a}$ such that any solution of (1) satisfies

$$
\lim _{t \rightarrow \infty} \inf S(t) \geq \bar{a}, \quad \lim _{t \rightarrow \infty} \inf I(t) \geq \bar{a}, \quad \lim _{t \rightarrow \infty} \inf R(t) \geq \bar{a}, \quad \lim _{t \rightarrow \infty} \inf E(t) \geq \bar{a},
$$

From Theorem 1, we get the disease free equilibrium $E_{1}$ is unstable for $R_{0}>1$. Now apply the uniform persistence result defined in [29], and then using the approach used to prove Proposition 3.3 of [30], it can be proved that system (2) is uniformly persistent in the region $\Omega$.

Theorem 3. Assume, $R_{0}>1$, then endemic equilibrium point $E_{2}^{*}$ is globally asymptotically stable if the following conditions hold:

(i) $\frac{1}{4} \beta_{e}^{2} E^{* 2}>R_{0}\left\{\frac{\alpha \mu \beta_{e} S^{*}}{\tau}+\frac{\gamma^{2}}{4}\right\}$ and $\operatorname{det}(M)>0$.

Proof. Consider a positive definite function

$$
V(t)=\frac{1}{2}\left(S-S^{*}\right)^{2}+\frac{1}{2}\left(I-I^{*}\right)^{2}+\frac{1}{2}\left(R-R^{*}\right)^{2}+\frac{1}{2}\left(E-E^{*}\right)^{2} .
$$


medRxiv preprint doi: https://doi.org/10.1101/2020.05.16.20104315; this version posted May 28, 2020. The copyright holder for this preprint (which was not certified by peer review) is the author/funder, who has granted medRxiv a license to display the preprint in perpetuity. It is made available under a CC-BY-NC-ND 4.0 International license .

Now differentiating $V$ with respect to $t$ along the solutions of system (2), we get

$$
\begin{aligned}
& \frac{d V}{d t}=\left(S-S^{*}\right) \dot{S}+\left(I-I^{*}\right) \dot{I}+\left(R-R^{*}\right) \dot{R}+\left(E-E^{*}\right) \dot{E} \\
& =\left(S-S^{*}\right)\left[r-S\left(\beta_{i} I+\beta_{e} E\right)-\mu S\right]+\left(I-I^{*}\right)\left[S\left(\beta_{i} I+\beta_{e} E\right)-(\mu+d+\gamma) I\right]+(R- \\
& \left.R^{*}\right)(\gamma I-\mu R)+\left(E-E^{*}\right)(\alpha I-\tau E) \\
& =\left(S-S^{*}\right)\left[-\mu\left(S-S^{*}\right)-\beta_{i}\left(S I-S^{*} I^{*}\right)-\beta_{e}\left(S E-S^{*} E^{*}\right)\right]-\left(I-I^{*}\right)^{2}[(\mu+d+\gamma- \\
& \left.\left.\beta_{i} S^{*}\right)\right]+\left(\beta_{i} I+\beta_{e} E^{*}\right)\left(S-S^{*}\right)\left(I-I^{*}\right)+\beta_{e} S\left(I-I^{*}\right)\left(E-E^{*}\right)-\mu\left(R-R^{*}\right)^{2}+\gamma(I- \\
& \left.I^{*}\right)\left(R-R^{*}\right)-\tau\left(E-E^{*}\right)^{2}+\alpha\left(I-I^{*}\right)\left(E-E^{*}\right) \\
& \leq-\mu R_{0}\left(S-S^{*}\right)^{2}-\frac{\alpha \beta_{e}(\mu+d+\gamma)}{\tau \beta_{i}+\alpha \beta_{e}}\left(I-I^{*}\right)^{2}-\mu\left(R-R^{*}\right)^{2}-\tau\left(E-E^{*}\right)^{2}+\beta_{e} E^{*}(S- \\
& \left.S^{*}\right)\left(I-I^{*}\right)-\frac{r \beta_{e}}{\mu}\left(S-S^{*}\right)\left(E-E^{*}\right)+\gamma\left(I-I^{*}\right)\left(R-R^{*}\right)+\left(\alpha+\frac{r \beta_{e}}{\mu}\right)\left(I-I^{*}\right)\left(E-E^{*}\right) \\
& =-X^{T} M X,
\end{aligned}
$$

where $X^{T}=\left\{\left|S-S^{*}\right|,\left|I-I^{*}\right|,\left|R-R^{*}\right|,\left|E-E^{*}\right|\right\}$ and $M=\left(a_{i j}\right)_{4 \times 4}$. Elements of the matrix $M$ are given by

$$
\begin{aligned}
& a_{11}=\mu R_{0}, a_{22}=\frac{\alpha \beta_{e}(\mu+d+\gamma)}{\tau \beta_{i}+\alpha \beta_{e}}, a_{33}=-\mu, a_{44}=-\tau, a_{12}=a_{21}=-\frac{1}{2} \beta_{e} E^{*}, a_{13}= \\
& a_{31}=0, a_{14}=a_{41}=\frac{1}{2} \frac{r \beta_{e}}{\mu}, a_{23}=a_{32}=-\frac{\gamma}{2}, a_{24}=a_{42}=-\frac{1}{2}\left(\alpha+\frac{r \beta_{e}}{\mu}\right), a_{34}=a_{43}=0 .
\end{aligned}
$$

Therefore, $M$ is positive negative if $(i) \frac{1}{4} \beta_{e}^{2} E^{* 2}>R_{0}\left\{\frac{\alpha \mu \beta_{e} S^{*}}{\tau}+\frac{\gamma^{2}}{4}\right\}$ and $\operatorname{det}(M)>0$.

Thus, $\frac{d V}{d t}<0$ and consequently $V$ is a Lyapunov function and hence endemic equilibrium point $E^{*}$ is globally asymptotically stable.

\section{Sensitivity Analysis and Numerical simulation}

Sensitivity analysis is one of the most important part to get an overview of most influential parameters in modelling of a infectious disease. As system stability determined by its reproduction number $\left(R_{0}\right)$, so we want to verify how the sensitive parameters are related with $R_{0}$ and therefore we compute the sensitivity analysis of $R_{0}$ with respect to the model parameters. By the definition of the normalized sensitivity index of $R_{0}$ with respect to $\beta$ is given by

$$
J_{\beta_{i}}^{R_{0}}=\frac{\partial R_{0}}{\partial \beta_{i}} \times \frac{\beta_{i}}{R_{0}}=0.87 .
$$

The sensitivity indices of $R_{0}$ with respect to other parameters are as follows:

$$
J_{\beta_{e}}^{R_{0}}=0.128, \quad J_{r}^{R_{0}}=1, \quad J_{d}^{R_{0}}=-0.06, \quad J_{\gamma}^{R_{0}}=-0.8488 .
$$

From this analysis we observed that, $J_{\beta_{i}}^{R_{0}}=0.87, J_{\beta_{e}}^{R_{0}}=0.128$, which implies if the direct and indirect disease transmission rate increase by $1 \%$ then it will increase the 
medRxiv preprint doi: https://doi.org/10.1101/2020.05.16.20104315; this version posted May 28, 2020. The copyright holder for this preprint (which was not certified by peer review) is the author/funder, who has granted medRxiv a license to display the preprint in perpetuity.

It is made available under a CC-BY-NC-ND 4.0 International license .
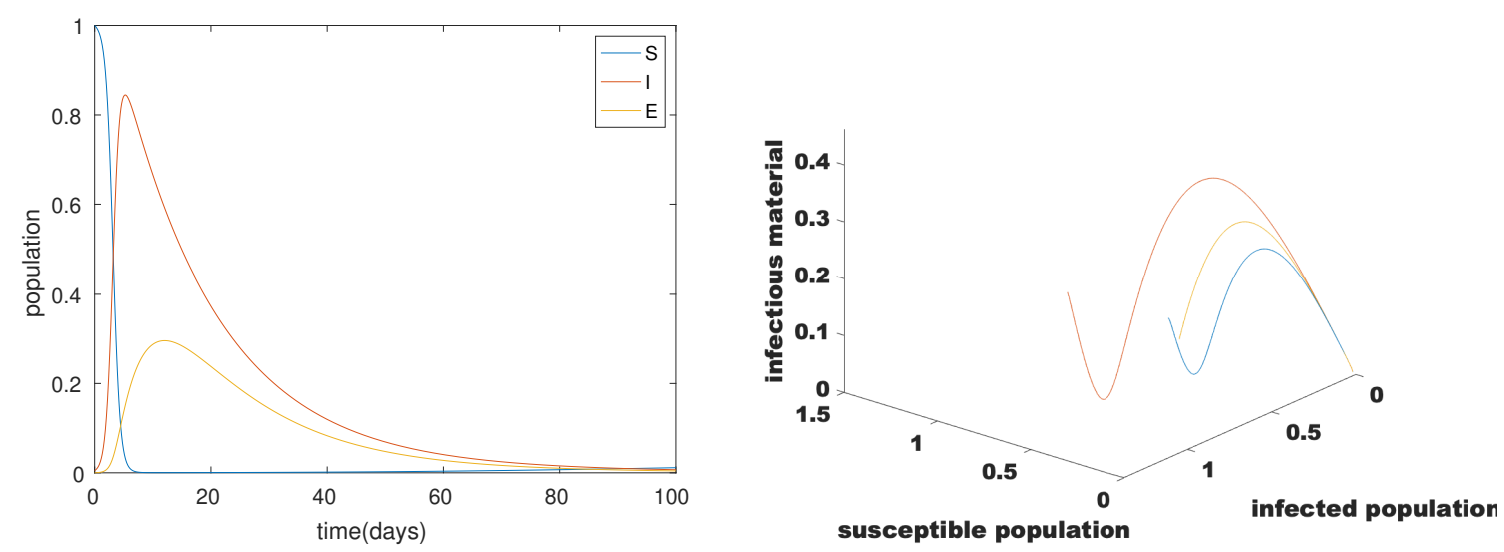

Figure 1: Dynamics of all population over time (days), and endemic equilibrium point is globally stable

value of $R_{0}$ by $0.87 \%$ and $0.128 \%$ respectively. Again, we see that $J_{\gamma}^{R_{0}}=-0.84<0$ that means increase the value of $\gamma$ by $1 \%$ then the value of $R_{0}$ will be reduced by $0.84 \%$. Thus, it can be concluded that reproduction number is positively corelated with $\beta_{i}$ and $\beta_{e}$ and negatively corelated with $\gamma$.

To observe the dynamics of our proposed model through numerically we set the following set of parameters hypothetically : $r=0.00045308 ; \beta_{i}=1.7[5] ; \beta_{e}=0.5[5] ; \alpha=$ $0.1 ; \mu=0.005 ; \gamma=0.05 ; \tau=0.2 ; d=0.0039$ [22]. For this set of parameters, we obtain $R_{0}=3.1794>1$, which satisfy the conditions of Theorem 3 and consequently the endemic equilibrium point is globally stable (Figure 1). From this figure we have seen that, susceptible population is decreasing but infected population is increasing over time that means more people are being infected within a short time period and as a result there is an outbreak within a short time span.

Till date, no vaccine or medicine is available to cure the disease properly so to prevent the disease transmission it is necessary to obey social distancing or lockdown which have already been applied by all Countries . The effectiveness of lockdown of 21 days or more days is described in Figure 2. From this figure, we observed that 21 days' lockdown is not sufficient to control the disease but if we would applied 54 days' lockdown or more then it shows that the lowest number of people would be infected and the epidemic might be under control. In Figure 3, we observed that how infected population is related with disease transmission rate. 
medRxiv preprint doi: https://doi.org/10.1101/2020.05.16.20104315; this version posted May 28, 2020. The copyright holder for this preprint (which was not certified by peer review) is the author/funder, who has granted medRxiv a license to display the preprint in perpetuity.

It is made available under a CC-BY-NC-ND 4.0 International license.

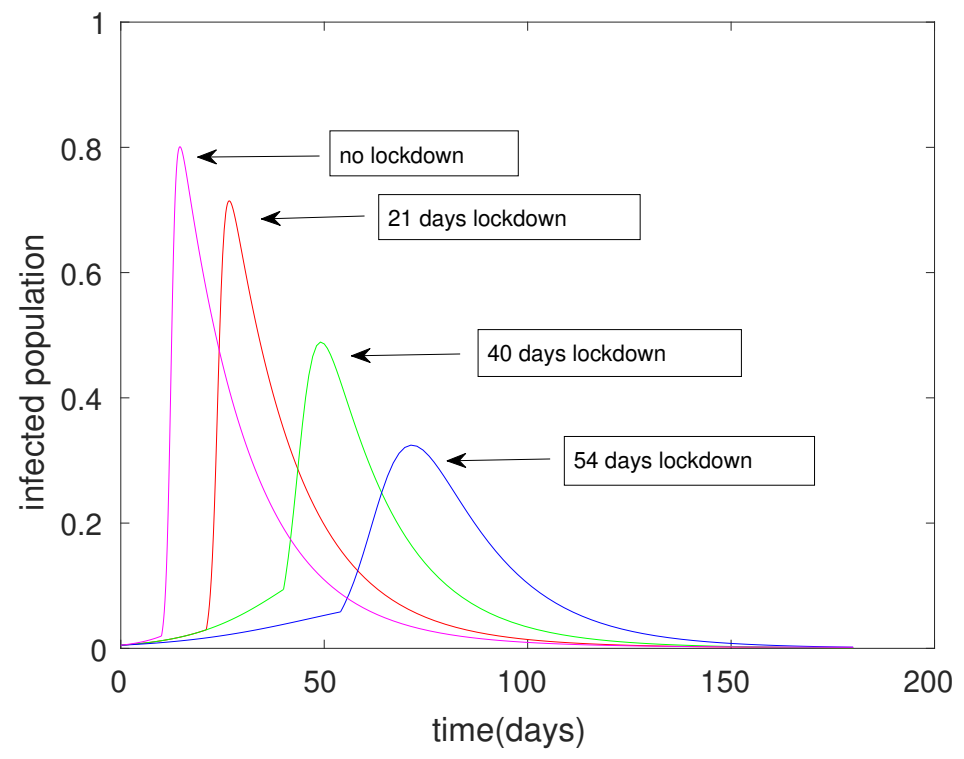

Figure 2: Infected population for different disease transmission rate

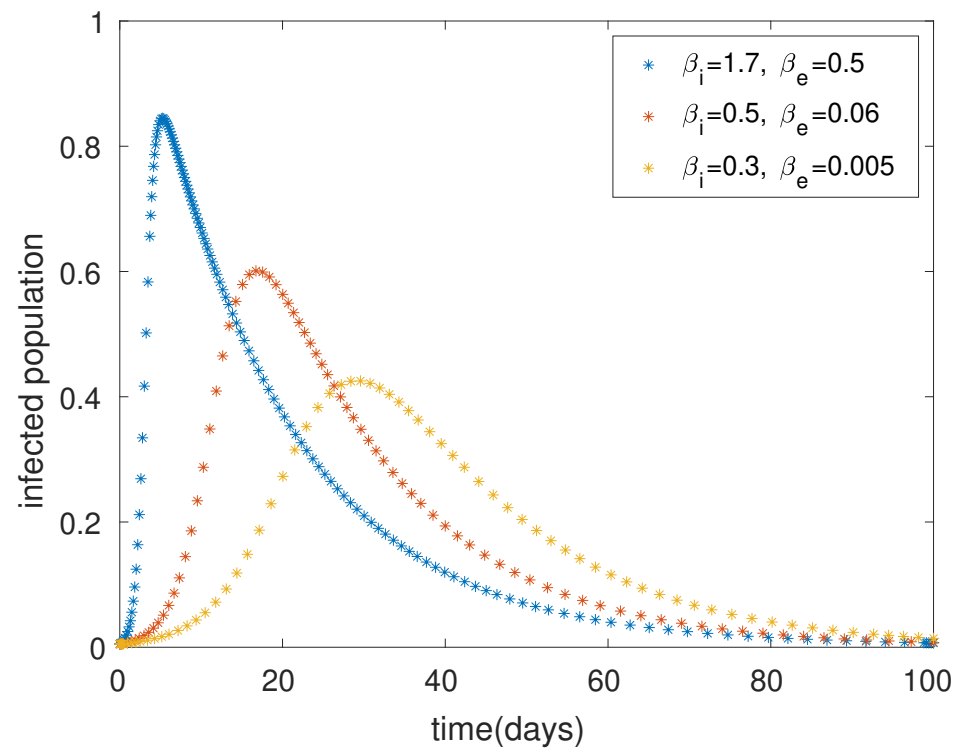

Figure 3: Dynamics of all population over time (days), and endemic equilibrium point is globally stable 


\section{Discussion}

Mathematical modelling is one of the best way to express the dynamics of an epidemic. In this paper, we have developed a mathematical model considering the direct and indirect disease transmission rates for COVID-19 outbreaks. The basic reproduction number for our considered model is given by

$$
R_{0}=\frac{r\left(\alpha \beta_{e}+\tau \beta_{i}\right)}{\mu \tau(\mu+d+\gamma)}
$$

The asymptotic behaviour of our model is determined by it's basic reproduction number. We observed that if $R_{0}<1$, then the disease-free equilibrium is globally asymptotically stable. If $R_{0}>1$, then disease persists in the system and endemic equilibrium point $E^{*}$ is globally asymptotically stable (see Figure 1.). From equation (9), we have also seen that the basic reproduction number is proportional to the recruitment rate of the susceptible population and directly as well as indirectly disease transmission rate, that means the probability of disease transmission is higher among the close contact or indirect contact with surfaces in the immediate environment or with objects used on the infected person. From sensitivity analysis it is noticed that basic reproduction number is positive corelated with $\beta_{i}$ while negatively corelated with $\gamma$. Thus to control the disease we must keep the basic reproduction number below the unity.

Conflict of interest: The author declare that there is no conflict of interest.

\section{References}

[1] https://talk.ictvonline.org.

[2] World Health Organization. Report of the WHO-China Joint Mission on Coronavirus Disease 2019 (COVID-19) 16-24 February 2020 [Internet]. Geneva: World Health Organization; 2020 Available from: https://www.who.int/docs/defaultsource/coronaviruse/who-china-joint-mission-on-covid-19-final-report.pdf

[3] Donnely CA, GhaniG AC, Leung M, et al. Epidemiological determinants of spread of causal agent of severe acute respiratory syndrome in Hong Kong. Lancet 361, 1761-1766. 2003.

[4] Cauchemez S, Fraser C, Van Kerkhove MD, et al. Middle East respiratory syndrome coronavirus: quantification of the extent of the epidemic, surveillance biases, and transmissibility. Lancet Infect Dis. 14, 50-56. 2014.

[5] https://www.worldometers.info/coronavirus/ 
medRxiv preprint doi: https://doi.org/10.1101/2020.05.16.20104315; this version posted May 28, 2020. The copyright holder for this preprint (which was not certified by peer review) is the author/funder, who has granted medRxiv a license to display the preprint in perpetuity. It is made available under a CC-BY-NC-ND 4.0 International license .

[6] https://www.who.int/emergencies/diseases/novel-coronavirus-2019

[7] Jiang F, Deng L, Zhang L, Cai Y, Cheung CW, Xia Z. Review of the clinical characteristics of coronavirus disease 2019 (COVID-19). Journal of General Internal Medicine, pp.1-5. 2020.

[8] Cai J, Sun W, Huang J, Gamber M, Wu J, He G. Indirect virus transmission in cluster of COVID-19 cases, Wenzhou, China, 2020. Emerg Infect Dis. 2020 Jun [date cited]. https://doi.org/10.3201/eid2606.200412. 2020.

[9] Zhang Y, Chen C, Zhu S et al. [Isolation of 2019-nCoV from a stool specimen of a laboratory-confirmed case of the coronavirus disease 2019 (COVID-19)]. China CDC Weekly;2(8):123-4. (In Chinese). 2020.

[10] Guo Z-D, Wang Z-Y, Zhang S-F, Li X, Li L, Li C, et al. Aerosol and surface distribution of severe acute respiratory syndrome coronavirus 2 in hospital wards, Wuhan, China, 2020. Emerg Infect Dis. 2020 Jul [date cited]. https://doi.org/10.3201/eid2607.200885

[11] Kamalich Muniz-Rodriguez, Gerardo Chowell, Chi-Hin Cheung, Dongyu Jia, Po-Ying Lai, Yiseul Lee, Manyun Liu, Sylvia K. Ofori, Kimberlyn M. Roosa, Lone Simonsen, and Isaac Chun-Hai Fung. Epidemic doubling time of the 2019 novel coronavirus outbreak by province in mainland china. medRxiv, 2020.

[12] Yang Yang, Qingbin Lu, Mingjin Liu, Yixing Wang, Anran Zhang, Neda Jalali, Natalie Dean, Ira Longini, M. Elizabeth Halloran, Bo Xu, Xiaoai Zhang, Liping Wang, Wei Liu, and Liqun Fang. Epidemiological and clinical features of the 2019 novel coronavirus out- break in china. medRxiv, 2020.

[13] Steven Sanche, Yen Ting Lin, Chonggang Xu, Ethan Romero-Severson, Nick Hengartner, and Ruian Ke. The novel coronavirus, 2019-ncov, is highly contagious and more infectious than initially estimated. medRxiv, 2020.

[14] Hiroshi Nishiura, Natalie M Linton, and Andrei R. Akhmetzhanov. Serial interval of novel coronavirus (2019-ncov) infections. medRxiv, 2020.

[15] Victor AO. Mathematical Predictions for COVID-19 as a Global Pandemic. 2020; medRxiv preprint.

[16] https://www.gavi.org/vaccineswork.

[17] Liu J, Liao X, Qian S et al. Community transmission of severe acute respiratory syndrome coronavirus 2, Shenzhen, China. Emerg Infect Dis 2020 doi.org/10.3201/eid2606.200239. 2020.

[18] Chan J, Yuan S, Kok K et al. A familial cluster of pneumonia associated with the 2019 novel coronavirus indicating person-to-person transmission: a study of a family cluster. Lancet. doi: 10.1016/S0140-6736(20)30154-9. 2020. 
medRxiv preprint doi: https://doi.org/10.1101/2020.05.16.20104315; this version posted May 28, 2020. The copyright holder for this preprint (which was not certified by peer review) is the author/funder, who has granted medRxiv a license to display the preprint in perpetuity.

It is made available under a CC-BY-NC-ND 4.0 International license .

[19] Li Q, Guan X, Wu P, et al. Early transmission dynamics in Wuhan, China, of novel coronavirus-infected pneumonia. N Engl J Med; doi:10.1056/NEJMoa2001316. 2020.

[20] Huang C, Wang Y, Li X, et al. Clinical features of patients infected with 2019 novel coronavirus in Wuhan, China. Lancet. 395: 497-506. 2020.

[21] Burke RM, Midgley CM, Dratch A, Fenstersheib M, Haupt T, Holshue M,et al. Active monitoring of persons exposed to patients with confirmed COVID-19 — United States, January-February 2020. MMWR Morb Mortal Wkly Rep. doi : 10.15585/mmwr.mm6909e1external icon. 2020.

[22] Wu P, Hao X, Lau EHY, et al. Real-time tentative assessment of the epi- demiological characteristics of novel coronavirus infections in Wuhan, China, as at 22 January 2020. Euro Surveill25 , 2000044.2020.

[23] Ong SW, Tan YK, Chia PY, Lee TH, Ng OT, Wong MS, et al. Air, surface environmental, and personal protective equipment contamination by severe acute respiratory syndrome coronavirus 2 (SARS-CoV-2) from a symptomatic patient. JAMA. 2020 Mar 4 [Epub ahead of print].

[24] https://www.who.int/news-room/commentaries/detail/modes-of-transmissionof-virus-causing-covid-19-implications-for-ipc-precaution-recommendations

[25] Birkhoff G, Rota CG. Ordinary Differential Equation. Ginn and Co., Boston. 1982.

[26] van den Driessche P, Watmough J. Reproduction numbers and subthreshold endemic equilibria for compartmental models of disease transmission. Math. Biosci. 180,29-48. 2002.

[27] Hale JK. Ordinary differential equations, John Wiley \& Sons, New York. 1969.

[28] Murray JD. Mathematical Biology, Springer-Verlag, Berlin. 1998.

[29] Safi M, Gumel AB. Dynamics of a model with quarantine-adjusted incidence and quarantine of susceptible individuals, J. Math. Anal. Appl. 399. 565-575. 2013.

[30] Li MY, Graef JR, Wang L. Global dynamics of a SEIR model with varying total population size, Math. Biosci. 160. 191-213. 1999. 